МЕТОДОЛОГІЧНЕ ПІДҐУНТЯ ІСТОРИКО-ПЕДАГОГІЧНОГО ВИСВІТЛЕННЯ ПРОБЛЕМИ ПІДГОТОВКИ МОЛОДІ ДО СІМЕЙНОГО ЖИТТЯ:
ПРИНЦИПИ ДОСЛІДЖЕННЯ

\author{
METHODOLOGICAL BASIS OF HISTORICAL AND PEDAGOGICAL \\ COVERAGE OF YOUTH PREPARATION FOR FAMILY LIFE PROBLEM: \\ RESEARCH PRINCIPLES
}

УДК 37

DOI https://doi.org/10.32843/2663-

$6085 / 2021 / 36.7$

\section{Ховрякова T.І.,}

аспірантка кафедри педагогіки

Криворізького державного

педагогічного університету
Стаття присвячена одній з актуальних проблем вітчизняної освіти - підготовці молоді до сімейного життя. Констатовано значну увагу вітчизняної педагогічної думки до виявленої проблеми на тлі сучасного розвитку суспільства та зазначено, що проблема має свою передісторію вивчення та розв'язання, тому стверджується, що історико-педагогічне висвітлення визначеної проблеми сприятиме виявленню позитивного досвіду, який варто врахувати відповідно до нинішніх реалій. На підставі звернення до вітчизняних психолого-педагогічних джерел зроблено висновки про артикуляцію проблеми переважно на встановленні причин, що призводять до недостатньої сформованості в сучасної української молоді психологічної готовності до шлюбно-сімейних відносин, та обмеженні уваги історико-педагогічних досліджень у визначеному напрямі питаннями поглядів педагогів минулого щодо статевого виховання молоді та їхнього ставлення до виконання батьківських обов'язків. Доведено, що в історико-педагогічному ракурсі проблема має бути висвітлена ширше, оскільки вона стосується також питань морального виховання учнівської молоді, ціннісної системи родинного виховання, розподілу гендерних ролей та моделей поведінки тощо. На основі звернення до наукових праць вітчизняних вчених щодо методології науково-педагогічних досліджень наголошено на відсутності «універсального» переліку методологічних принципів щодо науково-педагогічного дослідження та виявлено ті методологічні принципи, що, на думку автора, $є$ найбільш продуктивними у вивченні проблеми підготовки молоді до сімейного життя в історико-педагогічному ракурсі. До цих принципів зараховано принципи науковості, об'єктивності, детермінізму, єдності зовнішніх впливів і внутрішніх умов розвитку історизму та системності. Сукупність цих принципів має стати запорукою цілісного аналізу проблеми дослідження. Зроблено висновок, що виокремлені принципи становлять методологічну базу дослідження та слугують підгрунтям для встановлення методологічних підходів та виявлення конкретного дослідницького інструментарію (методів) щодо вивчення заявленої проблеми.

Ключові слова: методологія, методологічна принципи, науковість, об'єктивність, детермінізм, історизм, системність, підготовка молоді до сімейного життя.

The article is devoted to one of the current problems of national education - young people preparation for family life. Considerable attention of domestic pedagogical thought with regard to the identified problem on the ground of modern society is stated and it is also noted that the problem has its study and solution background, so it is asserted that the historical and pedagogical coverage of the problem will contribute to the identification of positive experiences that should be considered in accordance with current realities. Based on the appeal to domestic psychological and pedagogical sources, the following conclusions have been drawn: the articulation of the problem mainly on establishing the causes leading to insufficient maturity of modern Ukrainian youth for marital and family relations, and limited attention on past historical and pedagogical research on the sexual education of young people and their attitude to parental responsibilities. It is proved that in the historical and pedagogical perspective the problem should be covered more widely, as far as it concerns the following issues: moral education of students, the value system of family education, the distribution of gender roles and behavior patterns and more. Based on the appeal to the scientific works of domestic scientists on the methodology of scientific and pedagogical research, the lack of a "general" list of methodological principles for scientific and pedagogical research was emphasized and the methodological principles that, in the author's opinion, are the most productive in studying the problem of young people preparing for family life in the historical and pedagogical perspective are defined. These principles include the principles of scientificity, objectivity, determinism, unity of external influences and internal conditions for the development of historicism and systematics. The combination of these principles should become the key to a holistic analysis of the research problem. It is concluded that the selected principles constitute the methodological basis of the study and serve as a basis for establishing methodological approaches and identifying specific research tools (methods) to study the stated problem.

Key words: methodology, methodological principles, scientificity, objectivity, determinism, historicism, systematic approach, youth preparation for family life.
Постановка проблеми в загальному вигляді. Проблема підготовки молоді до сімейного життя нині $€$ надзвичайно злободенною, особливо в умовах скорочення населення України, що відбувається внаслідок дії низки фракторів, серед яких, на нашу думку, ключовим $є$ зменшення народжуваності через неготовність молоді до відпові- дального батьківства та вступу в шлюбно-сімейні відносини. Тому вітчизняна наукова, зокрема психолого-педагогічна думка, достатньо уважно ставиться до виявленої проблеми, аналізуючи ії̈ на тлі сучасного розвитку суспільства. Утім проблема має свою передісторію вивчення та розв'язання. Історико-педагогічне висвітлення визначеної 
проблеми, на нашу думку, сприятиме виявленню позитивного досвіду, який варто врахувати відповідно до нинішніх реалій.

Аналіз останніх досліджень і публікацій. Серед вітчизняних науковців, які в різний спосіб актуалізують питання готовності молоді до сімейного, життя варто назвати Т. Буленко, А. Денисенко, В. Захарченко, Л. Крижановську, О. Міненко, О. Скориніна-Погрібну та ін., які зосереджують свою увагу на психологічному аспекті проблеми. Зокрема, психологи виявляють тенденції щодо шлюбно-сімейних уявлень сучасної молоді [8] та пропонують низку діагностичних методик, які дають змогу виявити «найбільш актуальні проблеми в дошлюбний період» та сприяють створенню для респондентів напрямів корекційної програми [5]. Тобто наукові дослідження психології у визначеному напрямі переважно спрямовані на встановлення причин, що призводять до «недостатньої ссрормованості в сучасної української молоді психологічної готовності до шлюбно-сімейних відносин», та пошук відповідних корекційних методик «фрормування та корекції психологічної готовності молоді до шлюбно-сімейних відносин» [8, с. 193].

Дещо інший підхід до висвітлення питання пропонують педагоги, які артикулюють виховний аспект проблеми, зосереджуючи увагу на питаннях виховного впливу переважно на старшокласників і студентську молодь задля відновлення системи «сімейних цінностей» (І. Сіданіч), виховання в «юнаків і дівчат моральної готовності до того, як стати чоловіком і дружиною, батьком і матір'ю» (А. Красевич). За таких умов, за твердженням науковців, «педагоги мають акцентувати на моральнопсихологічних питаннях, розв'язання яких сприяло б фрормуванню правильних взаємин між статями, унеможливлювало статеву розпусту, закладало підвалини міцної сім”ї в майбутньому» [3, с. 58].

Виділення не вирішених раніше частин загальної проблеми. Представлені вище підходи до проблеми підготовки молоді до сімейного життя $€$ сталими, утім сама проблема, як зазначалося вище, не є новою (проте актуальною), тому педагогічною наукою накопичений значний досвід іiі розв'язання. Звернення до педагогічних праць 3 означеної проблеми переконує в залученні вітчизняними вченими до аналізу проблеми підготовки молоді до сімейного життя творчого спадку Я. Коменського, Ж.-Ж. Руссо, Дж. Локка, І. Песталоцці, М. Пирогова, К. Ушинського, П. Лесгафта, Б. Блонського, А. Макаренка, В. Сухомлинського, чиї педагогічні надбання становлять класику педагогічної думки. Утім використання досвіду педагогів минулого переважно стосується їхніх поглядів щодо статевого виховання молоді та їхнього ставлення до виконання батьківських обов'язків. Вважаємо, що в історико-педагогічному ракурсі проблема має бути висвітлена ширше, оскільки вона стосується також питань морального виховання учнівської молоді, ціннісної системи родинного виховання, розподілу гендерних ролей та моделей поведінки тощо. Отже, історико-педагогічне висвітлення питання підготовки молоді до сімейного життя потребує конкретизації методологічних засад, а саме системи наукових принципів, на яких базується її висвітлення.

Мета статті - окреслити методологічні засади висвітлення проблеми підготовки молоді до сімейного життя в історико-педагогічному аспекті.

Виклад основного матеріалу. Сучасна педагогічна наука стверджує, що необхідною умовою проведення якісного науково-педагогічне дослідження $€$ вивчення певного фракту, явища педагогічної дійсності з використанням відповідного методологічного апарату, тобто визначення сутності методології конкретного дослідження. Отже, історико-педагогічне висвітлення проблеми підготовки молоді до сімейного життя задля цілісності, ґрунтовності, послідовності дослідження та отримання доказових результатів також потребує встановлення відповідного предмета дослідження та його завдання, методології.

Передусім зазначимо, що у своїй роботі спираємося на погляди авторського колективу монографрії «Методологічні засади педагогічного дослідження»: «Розробка методології - це обґрунтування проєкту майбутнього педагогічного дослідження. Обґрунтована та реалізована методологія дозволяє досліднику отримати нове наукове знання» [7, с. 91]. Привабливою здається і позиція колективу авторів «Основ науково-педагогічних досліджень» (І. Аносов, М. Елькін, М. Головкова, А. Коробченко), які зазначають, що методологія аналізує та оцінює фрілософрські та світоглядні позиції, на які спирається дослідник, та «як вчення про способи та прийоми дослідження, методологія розглядає суттєві характеристики конкретних методів пізнання, що складають загальний напрям досліджень» [9, с. 16].

Генезис розв'язання проблеми підготовки молоді до сімейного життя має бути висвітлений 3 опорою на систему принципів наукового дослідження, методологічних підходів та сукупності методів (загально-наукових та конкретно-наукових). Попри взаємопов'язаність та взаємозумовленість визначених компонентів методології досліджені принципи відіграють ключову роль, оскільки $€$ базою для відбору певної системи методологічних підходів та методів як інструментів здійснення дослідження. За твердженням С. Важинського та Т. Щербак, «під принципом у науковій теорії розуміють найабстрактніше визначення ідеї (початкова форма систематизації). Принцип - це правило, що виникає у результаті суб'єктивно обдуманого досвіду людей» [1, с. 36]. Із визначених позицій звертаємо увагу на слушну думку авторів видання 
«Основи науково-педагогічних досліджень» (П. Лузан, І. Сопівник, С. Виговська) про те, що «методологічні принципи, конкретизовані умовами дослідження, виступають теоретичним підґрунтям у побудові методики дослідження» [10]. Серед принципів науково-педагогічного дослідження називають принципи: об'єктивності, сутнісного аналізу, генетичний, єдності логічного та історичного, концептуальної єдності дослідження, єдності динамічного і статичного (П. Лузан, І. Сопівник, С. Виговська); розвитку, загального зв'язку, діалектичної єдності теорії і практик, об'єктивності, єдності історичного і логічного, наступності, міждисциплінарності, всебічності (Ю. Агапов); детермінізму, відповідності та субсидіарності (С. Важинський, Т. Щербак); об'єктивності, сутнісного аналізу, генетичний та концептуальної єдності (В. Загвязинський) тощо. Наведені позиції вчених демонструють відсутність «універсального» переліку методологічних принципів щодо науково-педагогічного дослідження та спонукають до виявлення тих принципів, які $€$ найбільш продуктивними у вивченні проблеми підготовки молоді до сімейного життя в історико-педагогічному ракурсі.

Серед принципів, які, на нашу думку, варто покласти в основу дослідження зазначеної проблеми, варто зарахувати принципи науковості, об'єктивності, детермінізму, історизму та системності. Сукупність цих принципів стає запорукою цілісного аналізу проблеми дослідження, оскільки принцип науковості забезпечує належний сучасному рівню розвитку знань щодо проблем сім'ї та виховання розгляд проблеми, її логічне та послідовне розкриття 3 опорою на наявні в педагогічній науці концепції, теорії, погляди щодо порушеної проблеми. Принцип об'єктивності прямо пов'язаний із принципом науковості, оскільки забезпечує неупереджене та різнобічне висвітлення проблеми, дає змогу врахувати різні погляди на проблему дослідження та передбачає виключення «суб'єктивізму, однобічності і упередженості в підборі і оцінці фрактів» [2, с. 73].

На думку А. Литвина, який викладає позицію В. Загвязинсього, принцип об'єктивності «виражається в усебічному врахуванні чинників та умов, які породжують певне педагогічне явище, адекватності дослідницьких підходів і засобів; передбачає виключення суб'єктивізму, однобічності, упередженості в підборі й оцінюванні фрактів [6, с. 27]. Тому в розгляді проблеми підготовки молоді до сімейного життя цей принцип $€$ необхідним, оскільки допомагає уникнути оціночних суджень щодо правильності/неправильності поведінки молоді та встановити витоки тієї чи тієї поведінки, тобто виявити фрактори, що її детермінують. Отже, принцип детермінізму (спричинення) також стає одним із провідних у вивченні визначеної проблеми, оскільки дає змогу виявити систему зовнішніх впливів та внутрішніх умов розвитку проблеми дослідження, що загалом забезпечує цілісність проведеної роботи. У контексті вивчення становлення та розвитку педагогічних поглядів на проблему підготовки молоді до сімейного життя зважаємо на визначення сутності детермінізму, представлене С. Важинським та Т. Щербак, які зазначають, що «детермінізм виступає, перш за все, у формі причинності як сукупності обставин, які передують у часі якій-небудь даній події і викликають її. Тобто має місце зв'язок явищ і процесів, коли одне явище, процес (причина) за певних умов породжує, виробляє інше явище, процес (наслідок)» [1, с. 37]. Тому цей принцип є універсальним для науково-педагогічних досліджень та обов'язковим для досліджень історико-педагогічних, оскільки допомагає встановити зв'язок між подіями різного рівня та визначити рушійні сили розвитку педагогічного явища.

Експлікуючи думку авторів навчального посібника «Основи наукових досліджень» (згаданого вище) щодо дії принципу детермінації в дослідженні особистості на предмет нашого вивчення, можемо сказати, що принцип детермінізму фрормує три підсистеми детермінації: минуле, нинішнє та майбутнє [9, с. 30]. Тому власне цей принцип та історико-педагогічне спрямування вивчення проблеми підготовки молоді до сімейного життя визначають використання принципу історизму у висвітленні аналізованої проблеми. Використання принципу історизму в історико-педагогічному дослідженні також є обов'язковим, але його дотримання, на нашу думку, полягає не лише у хронологічному відтворення періодів, етапів розвитку того чи того явища, хоча саме таке тлумачення зустрічаємо в низці сучасних наукових публікацій. Прикладом такого тлумачення вважаємо працю О. Кизинець та I. Козинця «Розгляд і співставлення наявних у науковій літературі методологічних підходів і позицій науковців до розуміння проблеми управління розвитком шкіл передового досвіду в системі методичної освіти України другої половини XX - початку XXI ст.». Тут автори тлумачать принцип історизму як такий, що вимагає розгляду предмета дослідження «в динаміці, з урахуванням виявлених тенденцій, історичних і соціокультурних передумов» [4, с. 100]. На нашу думку, тут йдеться, скоріше, не про принцип історизму, а про використання історичного підходу до розглядуваного явища.

На нашу думку, опора на принцип історизму дає змогу відтворити розвиток явища в його історичному контексті, з урахуванням особливостей певних етапів його соціокультурного розвитку, зокрема в педагогічному аспекті. Цей принцип дає змогу уникнути оціночності суджень та сприяє об'єктивності висвітленні досліджуваного матеріалу, оскільки ті чи ті погляди науковців, що можуть здаватися нині застарілими та непродуктивними, 
свого часу могли мати прогресивний характер та загалом вплинули на розвиток проблеми, що досліджується. Тому принцип історизму передбачає урахування конкретних історичних умов формування та розвитку педагогічного явища/ проблеми, що можливе за умов дотримання принципу системності, завдяки якому відбувається упорядкування отриманих у процесі досліджень фрактів, структурна побудова самого дослідження як взаємозв'язку всіх його змістових елементів. Принцип системності забезпечує цілісність проведеного дослідження, валідність його висновків. Тому виявлені у процесі дослідження детермінанти (впливові чинники), що зумовлюють розвиток проблеми з урахуванням історичного контексту, становлять певну систему, що дає підстави для виявлення низки провідних тенденцій у генезі аналізованого явища.

Висновки. Викладений матеріал є лише початком системного пошуку методологічних основ вивчення проблеми підготовки молоді до сімейного життя в історико-педагогічній ретроспективі. Виокремлені принципи (науковість, об'єктивність, детермінізм, історизм та системність) становлять методологічну базу дослідження та слугують підґрунтям для встановлення методологічних підходів та виявлення конкретного дослідницького інструментарію (методів) щодо вивчення заявленої проблеми.

\section{БІБЛІОГРАФІЧНИЙ СПИСОК:}

1. Важинський С.Е., Щербак Т.І. Методика та організація наукових досліджень. Навчальний посібник. Суми : Сум ДПУ імені А.С. Макаренка, 2016, 2016. 260 с.
2. Гончаренко С.У. Педагогічні дослідження : Методологічні поради молодим науковцям. Київ - Вінниця : ДОВ «Вінниця», 2008. 278 с.

3. Каніболоцька Л.В., Кубіцький С.О. Формування готовності старшокласників до сімейного життя. Вісник Національного університету оборони України. 2013. № 4(35). С. 58-61.

4. Козинець О.Д., Козинець І.А. Розгляд і співставлення наявних у науковій літературі методологічних підходів і позицій науковців до розуміння проблеми управління розвитком шкіл передового досвіду в системі методичної освіти України другої половини XX - початку XXI ст. Вісник Черкаського універсиmemy. 2017. № 4. C. 96-105.

5. Крижановська Л.Г., Скориніна-Погребна О.В. Особливості емоційної готовності молоді до шлюбносімейних відносин. Проблеми екстремальної та кризової психології. 2016. № 20. С. 109-117.

6. Литвин А. Методологія у проекції педагогічних досліджень. Педагогіка і психологія профресійної освіти. 2014. №5. C. 20-35.

7. Методологічні засади педагогічного дослідження : монограсрія / авт. кол. : Є.М. Хриков, О.В. Адаменко, В.С. Курило та ін. Луганськ : Вид-во Д3 «ЛНУ імені Тараса Шевченка», 2013. 248 с.

8. Міненко О.О. Психологічна готовність молоді до шлюбно-сімейних відносин. Актуальні проблеми психології. 2019. Т.ІХ. Вип. 12. С. 186-195.

9. Основи науково-педагогічних досліджень : навчальний посібник / І.П. Аносов, М.В. Елькін, М.М. Головкова, А.А. Коробченко. Мелітополь : ТОВ «Видавничий будинок ММД», 2015. 218 с.

10. Основи науково-педагогічних досліджень / Лузан П.Г., Сопівник І.В., Виговська С.В. Київ, 2010. URL: $\quad$ https://bahmat.at.ua/MET_NAUK_DOSL/S. VYGOVSJKA_POSIBNYK.pdf. 